\title{
Teknologi Diversifikasi Produk Tahu di Desa Sumbersalak Kelurahan Kranjingan Kecamatan Sumbersari Kabupaten Jember Untuk Meningkatkan Pendapatan Rumah Tangga
}

\author{
Sukron Romadhona, Susan Barbara Patricia SM \\ Fakultas Pertanian, Universitas Jember \\ sukronromadhona.faperta@unej.ac.id
}

\begin{abstract}
Abstrak
Salah satu Industri Rumah Tangga (IRT) Tahu yang berada di Kabupaten Jember adalah di Desa Sumbersalak, Kelurahan Kranjingan, Kecamatan Sumbersari. Terdapat 2 produsen tahu yang tergabung dalam 1 IRT, dengan rata-rata bahan baku produksi 25 $\mathrm{kg} /$ hari untuk tahu dan $20 \mathrm{~kg} /$ hari untuk olahan kedelai lainnya, dengan tenaga kerja 4-6 orang. Permasalahan yang dihadapi IRT Tahu ini adalah: (1) Suara dari mesin penggilingan kedelai yang sangat bising, yang berbahaya bagi kesehatan telinga pekerja dan sering mendapat komplain dari warga sekitar, dan (2) Limbah pengolahan tahu yang berbau sering membuat masyarakat merasa tidak nyaman. Solusi untuk mengatasi masalah tersebut adalah dengan: (l) Observasi kegiatan produksi dan diskusi dengan produsen tahu untuk mengetahui permasalahan-permasalahan yang dihadapi dan yang dapat diatasi dan (2) Sosialisasi tentang peluang wirausaha produk olahan tahu dengan ibu-ibu yang berada di sekitar IRT tahu. Adanya pengabdian kepada masyarakat berbasis teknologi tepat guna ini diharapkan dapat: (1) Membantu IRT tahu dalam memperlancar kegiatan produksi, bahkan meningkatkan produksi, sehingga berpeluang untuk meningkatkan kapasitas industri yang pada akhirnya dapat menjadi lapangan pekerjaan bagi masyarakat sekitar, (2) membantu IRT untuk menurunkan polusi akibat aktivitas produksi sehingga tidak mengganggu kesehatan produsen, keluarga dan masyarakat sekitar, dan (3) Membantu masyarakat sekitar dan juga IRT Tahu dengan melakukan wirausaha prodak olahan tahu yang nilai jualnya akan lebih tinggi dan akan lebih besar jangkauan pasarnya.
\end{abstract}

Kata Kunci: Teknologi Tepat Guna, Pemberdayaan Masyarakat, Limbah Pabrik Tahu

\section{Abstract}

One of the Home Industry (IRT) knows that located in Jember Regency is in Sumbersalak Village, Kranjingan Village, Sumbersari District. There are 2 tofu producers incorporated in 1 IRT, with an average production of $25 \mathrm{~kg} /$ day for tofu and $20 \mathrm{~kg}$ / day for other soybeans, with a workforce of 4-6 people. Knowing these problems are: (1) Sounds from soybean milling machines that are very noisy, which are hazardous to the health of workers and often get complaints from local residents, and (2) Tofu processing waste that makes people uncomfortable. The solutions to overcome these problems are by: (1) Observing production activities and discussions with producers to tofu the competencies that discuss and can overcome (2) Disseminating information about entrepreneurial opportunities for processed products with mothers who depend on IRTs to Tofu. The availability of appropriate technology-based community service is expected to be able to: (1) Help know IRTs in facilitating production activities, even increasing production, so that the opportunity to increase industrial capacity can ultimately reach 
employment opportunities for surrounding communities, (2) assist IRTs to Income from producers, families and the surrounding community, and (3) Helping surrounding communities and IRTs to tofu that by doing processed entrepreneurship products, they tofu that the selling value will be higher and will be greater than the market.

Keywords: Appropriate Technology, Community Empowerment, Tofu Mill Waste

\section{PENDAHULUAN}

Desa Sumbersalak berada dalam wilayah Kecamatan Sumbersari, Kabupaten Jember yang termasuk daerah Waspada Pangan dan Gizi, berdasarkan data Peta Kerawanan Pangan dan Gizi dari Badan Perencanaan Pembangunan Daerah Kabupaten Jember. Meskipun masuk dalam kategori Waspada Pangan dan Gizi, Desa Sumbersalak memiliki potensi tinggi dalam usaha produksi Tahu yang dikelola oleh salah satu Industri Rumah Tangga (IRT) di desa tersebut. Saat ini, produksi Tahu masih menggunakan teknologi tradisional, tanpa pengemasan, dan limbah padat serta cair yang masih belum bisa dimanfaatkan secara maksimal, padahal pemanfaatan limbah pengolahan tahu dapat meningkatkan pendapatan IRT.

Selain itu, limbah cair masih berbau menyengat yang dihasilkan dari asam cuka tahu proses pembuatan tahu yang dapat mencemari lingkungan. Oleh karena itu, perlu adanya teknologi pembuatan tahu yang ramah lingkungan (tidak dihasilkan cairan limbah yang berbau) dan mampu meningkatkan kualitas dari tahu yang dihasilkan baik dari segi gizi, rasa dan aromanya yaitu dengan menggunakan bahan koagulan (penggumpal) yang ramah lingkungan yaitu "Nigarin", dengan tehnik pengemasan tahu yang higienis dan sterilisasi pada tahu yang dihasilkan dengan pasteurisasi untuk membunuh bakteri patogen yang berbahaya yaitu Bacillus cereus dan Staphylococcus aureus yang mengontaminasi tahu selama proses pembuatan tahu. Selain itu, tahu yang dihasilkan diolah menjadi produk makanan yang bernilai jual tinggi yaitu nugget tahu, sosis tahu dan stik tahu serta limbah yang dihasilkan dari pembuatan tahu dengan koagulan "Nigarin" dapat dimanfaatkan sebagai pakan ternak dan minuman menyehatkan sehingga harapannya dapat meningkatkan pendapatan IRT Desa Sumbersalak.

Tahu sebagai salah satu makanan tradisional sangat penting untuk dikembangkan, sehingga perlu dilakukan usaha-usaha pembinaan terhadap industri rumah tangga yang mencakup: a) Peningkatan cara penyajian makanan tradisional dengan memanfaatkan alat atau peralatan hasil teknologi baru dan disajikan dengan cara yang lebih cepat dan menarik. b) Peningkatan mutu makanan tradisional baik fisik, mutu gizi maupun mutu citarasa serta menigkatkan sanitasi makanan dan lingkungan. c) Peningkatan nilai sosial ekonomi makanan tradisional. d) Peningkatan usaha memasyarakatkan dan memperluas cakupan konsumen pangan tradisional di daerah lain di luar daerah asal makanan yang bersangkutan. e) Peningkatan kemampuan modal pemilik usaha makanan tradisional untuk mampu mengembangkan usahanya. Sehubungan dengan kegiatan pelatihan ini maka orientasi program adalah pengembangan usaha dengan pengenalan teknologi pembuatan tahu 
yang ramah lingkungan dan higienis, pengolahan pasca tahu, teknik pengemasan dan manajemen pemasaran, dengan tujuan: 1) Mengetahui dan mempraktekan pemilihan dan penggunaan bahan serta teknik olah dalam pembuatan tahu. 2) Mengetahui dan mempraktekkan pengembangan produk tahu sehingga dapat diterima oleh masyarakat secara luas. 3) Mengetahui dan menerapkan sanitasi higiene pada produksi tahu. 4) Mengetahui dan menerapkan cara perhitungan perolehan keuntungan dan titik impas produksi tahu.

Penerapan IPTEKS yang dimaksud dalam kegiatan ini mengembangkan teknik pengolahan makanan dengan mengaplikasikan teknologi proses pengolahan tahu yang ramah lingkungan dan berkualitas baik serta pengolahan pasca tahu, baik untuk makanan bentuk basah dan kering. Harapannya dengan adanya pelatihan teknologi pengolahan tahu dan pengolahan pasca tahu, teknologi pengemasan maupun pemasaran pengrajin telah dapat mengembangkan produk tahu menjadi makanan lain yang memiliki nilai jual dan jangkauan pemasaran yang lebih baik, dan tahu Sumbersalak dapat menjadi unggulan dan kebanggaan masyarakat.

\section{METODE}

Kegiatan PKM ini difokuskan pada teknologi pengolahan tahu yang ramah lingkungan dan higienis dengan penggunaan bahan penggumpal (koagulan) "Nigarin" dengan tehnik pengemasan yang tepat dan tehnik sterilisasi tahu dengan pasteurisasi serta pelatihan pembuatan produk-produk berbahan dasar tahu dan tehnik pemasarannya dengan menggunakan pendekatan Pemberdayaan Masyarakat pada industri Tahu di Desa Kranjingan Kabupaten Jember. Adapun langkah-langkah yang dilakukan: sosialisasi dan pelatihan teknologi pengolahan tahu yang ramah lingkungan dan higienis dengan penggunaan bahan penggumpal (koagulan) "Nigarin" dengan tehnik pengemasan yang tepat dan tehnik sterilisasi tahu dengan pasteurisasi serta pembuatan produk-produk berbahan dasar tahu dan tehnik pemasarannya, menyiapkan sarana dan prasarana berbasis TTG penunjang proses produksi, penyempurnaan sistem administrasi produksi, monitoring dan evaluasi, tindak Lanjut paska program. Secara umum, proses pembuatan tahu dengan bahan koagulan "Nigarin" sama dengan proses pembuatan tahu pada umumnya, perbedaannya adalah pada zat koagulan. Proses Pembuatan Tahu dengan bahan koagulan "Nigarin" dapat dilihat pada Gambar 1 


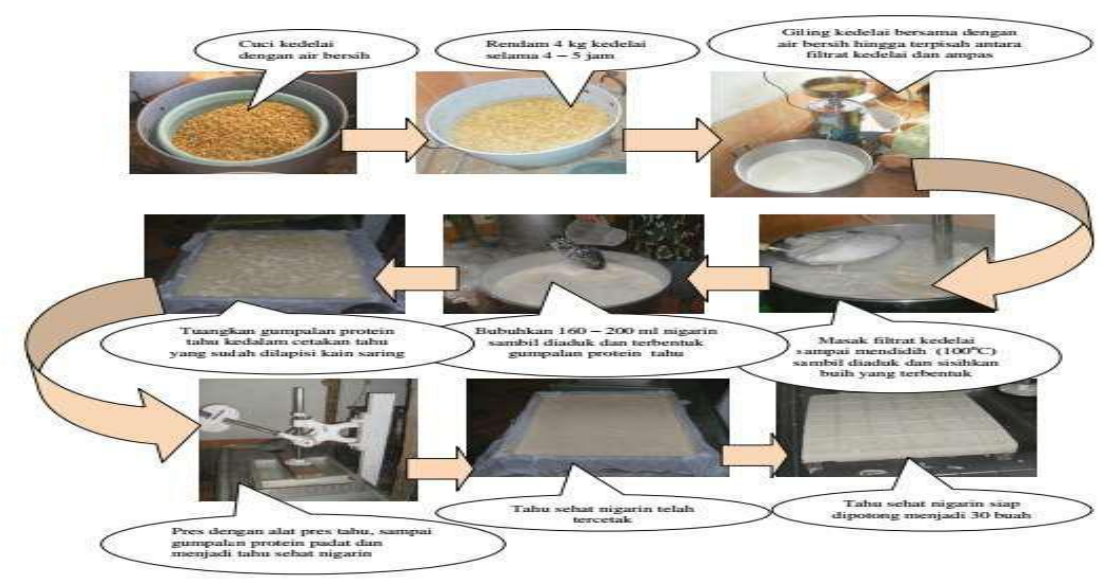

Gambar 1. Proses Pembuatan Tahu Dengan Bahan Koagulan "Nigarin".

Dalam proses tersebut untuk alat yang digunakan masih sama dengan alat-alat yang digunakan pada proses pembuatan tahu pada umumnya. Jadi alat-alat sebelumnya yang digunakan oleh pengrajin tahu untuk memproduksi tahu dengan bahan koagulan asam cuka, whey, batu tahu, atau $\mathrm{CaCl} 2$ masih bisa digunakan.

\section{A. Teknologi Pengemasan}

Teknologi pengemasan tahu dengan menggunakan alat cup sealer, sehingga tahu yang dikemas dapat bertahan lama dipasar dan lebih menarik.

B. Teknologi Sterilisasi Tahu

Teknologi sterilisasi tahu dengan pasteurisasi yaitu pemanasan dengan air suhu $110^{\circ} \mathrm{C}$ selama 7 menit.

\section{Teknologi Pengolahan Limbah}

Pengolahan limbah pembuatan tahu dengan bahan koagulan "Nigarin" dapat dilihat pada Gambar 2.

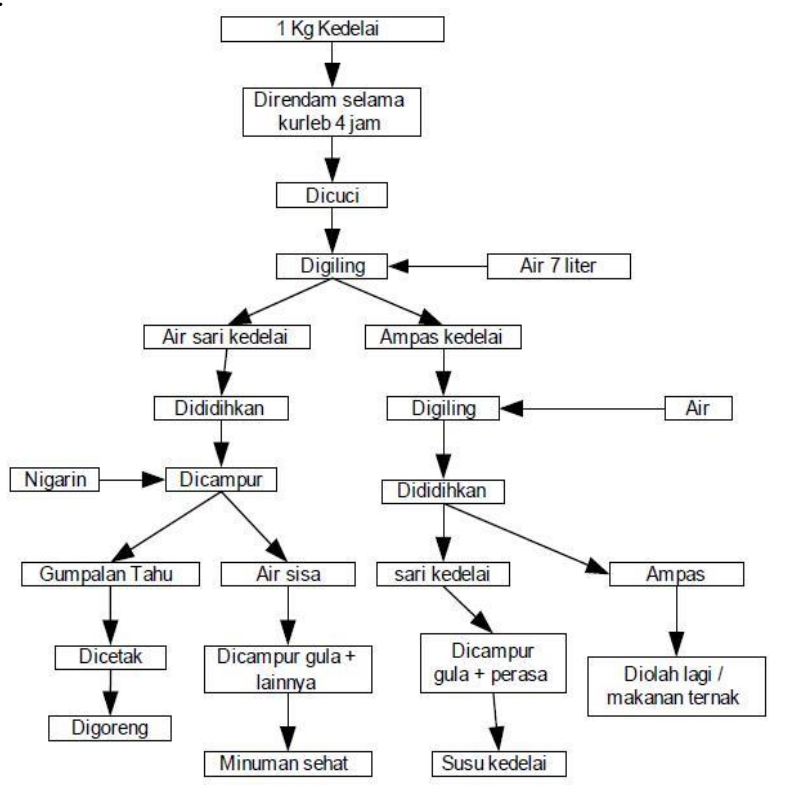

Gambar 2. Teknologi Pembuatan Tahu Dengan Bahan Koagulan "Nigarin" Dan Pengolahan Limbahnya. 
Pelatihan pada industri Tahu di Desa Kranjingan Kabupaten Jember diharapkan dapat meningkatkan pengetahuan, daya inovasi, kreatifitas, dan manajemen usaha dalam upaya memproduksi tahu yang ramah lingkungan dan higienis dengan penggunaan bahan penggumpal (koagulan) "Nigarin", dipadukan dengan teknik pengemasan yang tepat, teknik sterilisasi, pelatihan pembuatan produk-produk berbahan dasar tahu, dan teknik pemasarannya. Peningkatan pengetahuan dan manajemen usaha dalam pembuatan tahu dan produk-produk turunan tahu dapat dilakukan melalui kegiatan: strategi pemberdayaan masyarakat, kewirausahaan, perencanaan usaha, praktek pembuatan tahu yang ramah lingkungan dan pembuatan produk turunan tahu yang higienis, praktek teknik operasi peralatan, dan kesehatan lingkungan.

Teknologi yang akan di Introduksikan, teknologi yang dapat menunjang kualitas dan kuantitas produksi: teknologi pokok berupa alat untuk memproduksi tahu, pengemasan, sterilisasi tahu dan pengolahan limbah pembuatan tahu yang sesuai keinginan masyarakat, teknologi pengolahan limbah pembuatan tahu, teknologi pembuatan produk-produk turunan tahu (nugget tahu, sosis tahu dan stik tahu) sesuai dengan alat yang dimiliki.

\section{HASIL DAN PEMBAHASAN}

Konsolidasi kegiatan pengabdian dilakukan oleh beberapa mahasiswa Fakultas Pertanian Universitas Jember beserta dosen pendamping yang memiliki keahlian dibidang teknologi pangan dan lingkungan. Konsolidasi kegiatan dengan Ketua Industri Rumah Tangga Tahu Kranjingan untuk pemantapan persiapan kegiatan yang akan dilaksanakan pada hari berikutnya. Dalam konsolidasi ini, pengrajin tahu menjelaskan tahapan proses pembuatan tahu, bahan-bahan yang digunakan, serta halhal yang perlu diperhatikan dalam pembuatan tahu. Kegiatan ini bertujuan untuk mendapatkan informasi yang penting dalam pelaksanaan kegiatan pengabdian. Gambar 4 merupakan foto kegiatan di lokasi produksi, terlihat mahasiswa/i dan dosen memperhatikan penjelasan dan proses produksi tah

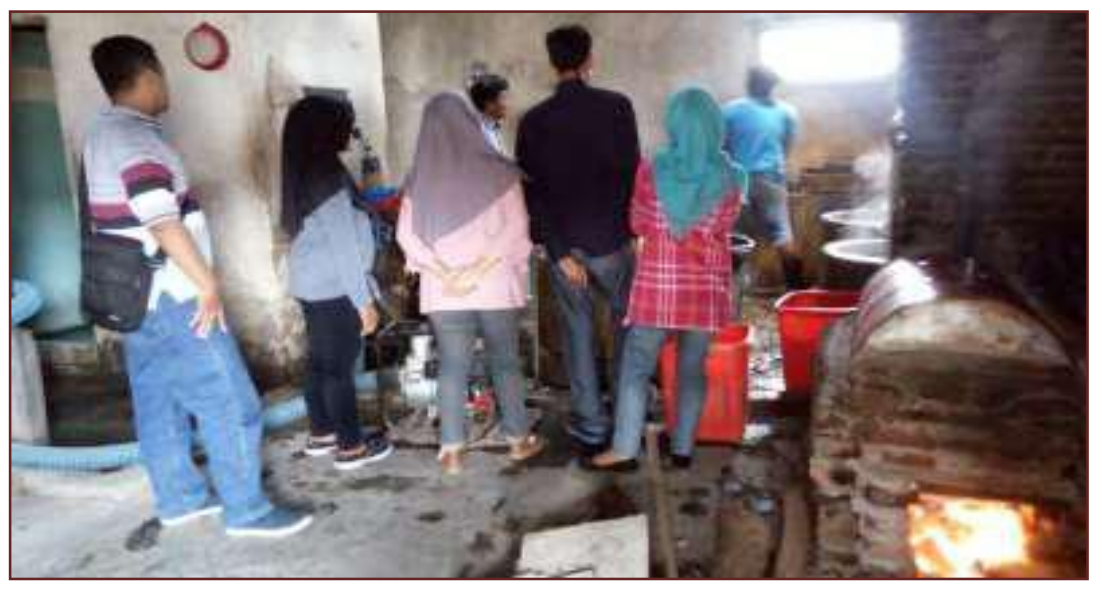

Gambar 4. Koordinasi Kegiatan oleh Tim dan pengrajin IRT Tahu Kranjingan. 
Melalui hasil observasi dan diskusi tim dengan pengrajin tahu, proses produksi tahu di IRT Kranjingan memiliki banyak persoalan yang harus segera diselesaikan, salah satunya adalah berkaitan dengan mesin produksi penngiling kedelai, karena menggunakan mesin penggiling yang sudah lama sehingga produksi mereka sering kali turun, karena mesin penggiling yang merupakan salah satu alat utama dalam proses produksi tahu sering kali mengalami kerusakan sehingga beberapa kali pengrajin harus berhenti produksi. Kemudian persoalan berikutnya yaitu tingkat kebisingan yang dihasilkan oleh mesin penggiling, menurut Ketua Kelompok IRT Kranjingan, persoalan kebisingan ini sering kali terjadi yaitu pengrajin tahu sering mendapat komplain dari tetangga karena suara yang dihasilkan oleh mesin penggiling, oleh karena itu kami hibahkan mesin penggiling yang ramah suara.

Dalam upaya menunjang kegiatan usaha produksi tahu di Industri Rumah Tangga Tahu Kranjingan tim pengabdian masyarakat memberikan beberapa peralatan yang dapat mendukung proses produksi seperti mesin penggiling kedelai, rangka mesin penggiling kedelai, pengaduk sari tahu, alat-alat lainnya. Produksi tahu yang merupakan usaha rumah tangga untuk mendukung perekonomian rumah tangga. Pemberian alat-alat ini dirasa perlu karena kondisi peralatan yang dimiliki pengrajin sudah sangat tua, mesin kurang lebih berumur 5 tahun. Hal ini sering mengganggu proses produksi. Beberapa kali mesin tidak dapat dipopersikan dan harus diperbaiki. Proses perbaikan sering kali membutuhkan waktu 5-4 jam, sehingga sering membuat kegiatan produksi terpaksa libur. Gambar 5 menunjukkan kondisi mesin yang dimiliki industri rumah tangga tahu Kranjingan.

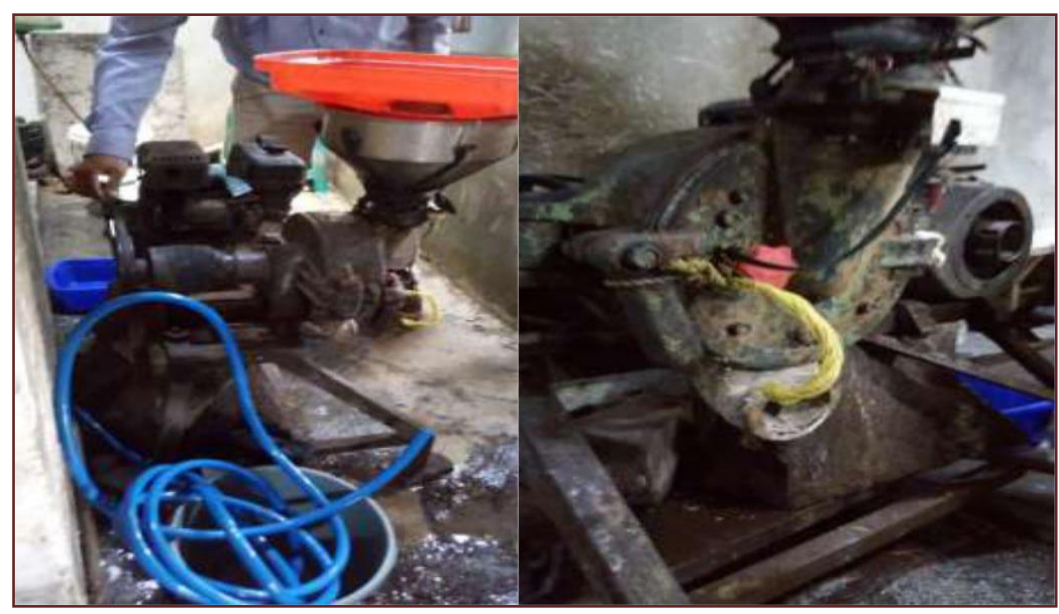

Gambar 5. Mesin Penggiling Kedelai IRT Tahu Kranjingan.

Bukan hanya masalah mesin yang sering tidak dapat beroperasi dengan baik, mesin penggilingan kedelai ini juga sangat bising saat beroperasi. Hal ini tentu menjadi sumber polusi suara yang tidak baik bagi kesehatan pengrajin terutama dan yang juga sering mengganggu keluarga dan masyarakat sekitar industri rumah tangga ini. Peralatan yang dirakit, dibeli dan diberikan oleh tim pengabdian masyarakat 
dalam kegiatan ini merupakan mesin penggilingan dengan kemampuan/ kapasitas produksi yang lebih besar dari mesin yang sebelumnya.

Alat penggilingan yang baru juga mengeluarkan suara yang lebih ringan dari mesin yang sebelumnya. Gambar 6 menunjukkan percobaan alat penggilingan yang baru oleh pengrajin tahu disaksikan oleh tim pengabdian. Hasil dan pembahasan berisi hasil-hasil kegiatan pengabdian kepada masyarakat dan pembahasannya. Tuliskan temuan-temuan yang diperoleh dari hasil-hasil kegiatan yang telah dilakukan dan harus ditunjang oleh data-data yang memadai. Hasil-hasil kegiatan pengabdian kepada masyarakat dan temuan harus bisa menjawab permasalahan di bagian pendahuluan

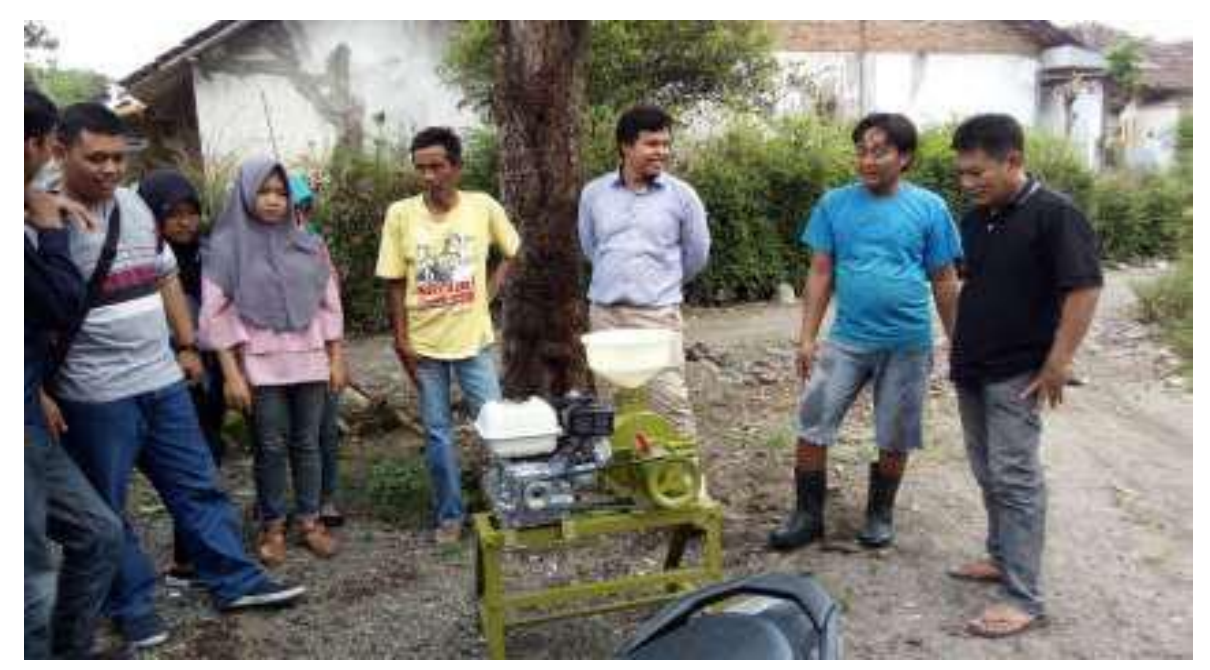

Gambar 6. Percobaan Alat Penggilingan Kedelai oleh Pengrajin Tahu.

Peralatan mesin penggiling kedelai diletakkan di rumah ketua kelompok usaha sehingga nantinya mesin penggiling kedelai ini dapat dimanfaatkan bersama. Dalam upaya mengatur produktivitas tahu yang diproduksi, masing-masing pengrajin diberikan sejumlah alat dan informasi untuk mendukung dalam pembuatan tahu seperti pengaduk adonan tahu, cara membuat penggumpal adonan tahu dan alat lainnya, sehingga tidak ada perbedaan dari masing-masing keluarga dari segi kualitas bahan dan alat yang digunakan dalam proses produksi tersebut. Secara ekonomi pengrajin tahu mengaku masih belum sejahtera dengan usaha ini, karena memang usaha ini dimulai dengan layanan peminjaman uang dari bank, sehingga masih harus membayar cicilan setiap bulannya. Salah satu upaya untuk meningkatkan pendapatan adalah dengan peningkatkan produksi. Peningkatan produski pertama terkendala pada mesin, karena mesin sudah tidak dapat beroperasi dengan baik, sehingga pengabdian ini diharapkan dapat mengatasi masalah mesin. Hal yang kedua adalah tenaga kerja, ketua industri rumah tangga mengaku belum mampu membayar upah tenaga kerja tambahan, sehingga masih memanfaatkan tenaga anggota keluarga yang terbatas. Melalui beberapa kendala ini tim pengabdian menganjurkan untuk meningkatkan pendapatan dengan diversifikasi produk. 
Diversifikasi produk olahan tahu diarahkan agar dapat dikerjakan oleh para ibu rumah tangga yang tidak mempunyai penghasilan. Bahan baku yang digunakan adalah tahu hasil produksi industri rumah tangga sendiri dan juga tahu yang tidak terjual pada pagi hari, sehingga tidak perlu penyimpanan yang akan menyita waktu dan biaya karena tahu produksi Kranjingan merupakan tahu yang tidak menggunakan bahan pengawet. Hal ini menyebabkan tahu akan mudah rusak (fisik, rasa). Secara fisik akan mudah menguning bila tidak direndam dengan air bersih dan akan cepat masam dari segi rasa. Beberapa produk olahan tahu yang dipraktekan untuk dapat diproduksi serta dipasarkan adalah kerupuk tahu, stik tahu dan tahu petis. Ada banyak produk olahan tahu lain sebenarnya yang dapat dibuat oleh para ibu rumah tangga nantinya sesuai kreatifitas dan permintaan pasar. Gambar 7 merupakan contoh produk olahan tahu.

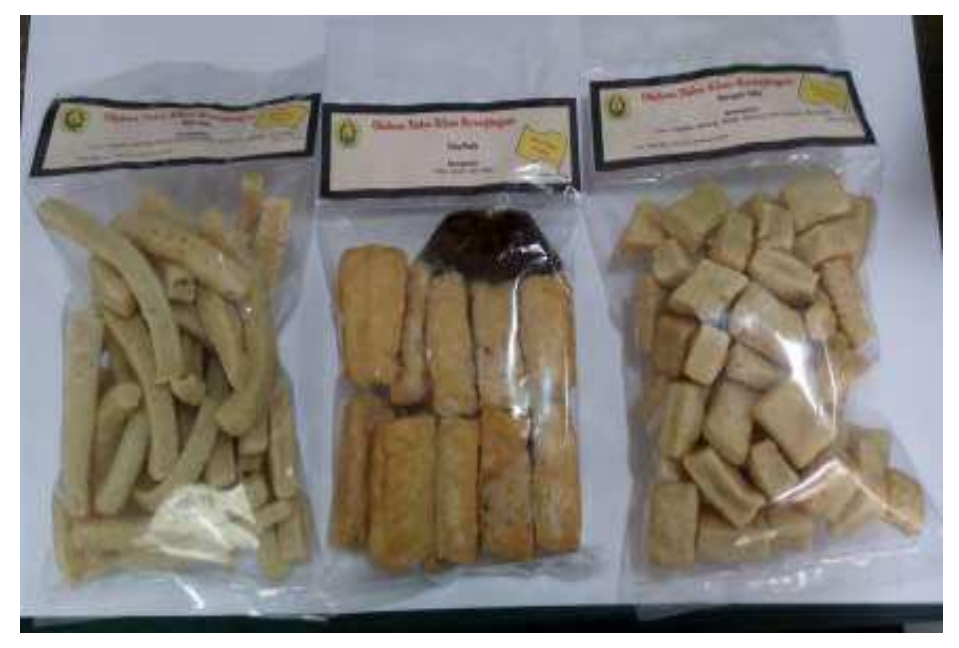

Gambar 7. Produk Olahan Tahu Kranjingan

Setelah dilakukan pelatihan ini harapannya kegiatan yang sudah terlaksana dapat memberikan dampak yang berkelanjutan sehingga dapat menjadi program desa yang bias menjadi alternatif usaha bagi para ibu rumah tangga secara khusus yaitu memiliki produk sampingan dari pengelolaan tahu yang mampu bersaing secara kualitas. Untuk itu kami membentuk kelompok usaha bersama yang nantinya akan menjadi wadah bagi para pelaku usaha produk olahan tahu di IRT Kranjingan, harapanya dengan melakukan pembentukan kelembagaan yang dibentuk untuk mejadi bagian dari pemberdayaan masyarakat Usaha Mikro ini, selanjutnya yaitu yang dilakukan adalah memberikan pelatihan kepada masyarakat pelaku usaha tentang bagaiamana pelatihan manajemen pemasaran produk-produk olahan tahu ini yang akan menjadi bagian rangkaian kegiatan pengabdian ini.

\section{KESIMPULAN}

Pendampingan terhadap masyarakat IRT Kranjingan ini memiliki manfaat yang bagus, selain dapat memberikan pilihan alternatif produk olahan tahu, masyarakat juga dapat meningkatkan pendapatan dari sektor lain, sehingga tidak ketergantungan 
terhadap produk tahu jadi. Pemberian pelatihan diversifikasi bahan olahan dari tahu dapat membuka lapangan kerja baru. Produksi tahu dapat lebih stabil dengan tidak bermasalah pada mesin sekaligus menyelesaikan persoalan sosial yang ditimbulkan dari proses produksi tahu yaitu kebisingan. Program Kemitraan Masyarakat merupakan program yang tepat bagi pemberdayaan ekonomi masyarakat Usaha Mikro, Kecil dan Menengah dengan memberikan fasilitas, pelatihan dan pendampingan. Untuk lebih meningkatkan dan memantapkan program tersebut, maka perlunya pendampingan dana, pelatihan, dan pengawasan secara intensif terhadap program yang telah direncanakan, sehingga masyarakat yang telah dibina menjadi lebih mantap dalam manjalankan usaha untuk meningkatkan pendapatan dan kesejahteraan.

\section{DAFTAR PUSTAKA}

Amarsari, N.F. (2010). Perbedaan Kadar Magnesium, Lama Simpan, Daya Terima dan Kekenyalan Pada Tahu Dengan Penggumpalan Whey dan Nigarin. Jurusan Ilmu Gizi, Fakultas Kedokteran,Universitas Diponegoro.

Nugrahani, E.V. (2014). Pembuatan Koagulan Tahu dari Air Laut yang Dipekatkan Melalui Pemanasan pada Beberapa Tingkat Konsentrasi. Jurusan Kimia, Fakultas Matematika dan Ilmu Pengetahuan Alam,Universitas Jember.

Purwantari, H., dkk..(2015). Perancangan dan Uji Kinerja Pasteurizer Tahu. Jurusan Teknologi Pangan dan Hasil Pertaian, Fakultas Teknologi Pertanian UGM. Prosiding Seminar Agroindustri dan Lokakarya Nasional FKPT-TPI Program Studi TIP-UTM, 2-3 September 2015.

Riant, N. dan Randy W. (2007) Manajemen Pemberdayaan: Sebuah Pengantar \& Panduan untuk Pemberdayaan Masyarakat, Elex Media Komputindo, Jakarta. Widaningrum, I. (2015). Teknologi Pembuatan Tahu Yang Ramah Lingkungan (Bebas Limbah). Fakultas Teknik,Universitas Muhammadiyah Ponorogo. JURNAL DEDIKASI, ISSN 1693-3214 